\title{
Analysis of A Sequence Nucleotide Polymorphism of STAT5A Gene in Garganica Goat Breed
}

\author{
Maria Selvaggi, Fedrica Ioanna, Francesco Pinto, Cataldo Dario \\ Department of DETO, Section of Veterinary Science and Animal Production, \\ University of Bari “Aldo Moro”, Valenzano 70010, Italy \\ E-mail: maria.selvaggi@uniba.it
}

\begin{abstract}
STATs (signal transducer and activator of transcription) are a group of transcription factors that mediate actions of a variety of peptide hormones and cytokines within target cells (for example prolactin and growth hormone). In particular, STAT5A gene is a candidate marker for quantitative traits in farm animals. In this study, the STAT5A/Eco81I polymorphism was investigated with PCR-RFLP in a sample of Garganica goats. Garganica breed is an Italian goat breed that originates in the Gargano promontory, in Apulia region, by crossing the autochthonous population of goat with west European goats. Garganica breed show an exceptional ability to adapt to particularly difficult environments, as well as an extraordinary capacity to utilize poor pasture that would not otherwise be used. The investigated polymorphism is a substitution $C \rightarrow T$ at position 6852 within the exon 7 of the STAT5A gene. Only two out of three possible genotypes were identified in the population. The allelic frequencies of alleles $\mathrm{C}$ and $\mathrm{T}$ were 0.863 and 0.137 respectively and the population was kept in Hardy-Weinberg equilibrium. Moreover, some population genetic indices were also reported.
\end{abstract}

Keywords - STAT5A gene; single nucleotide polymorphism; Garganica goat.

\section{INTRODUCTION}

The STAT (signal transducer and activator of transcription) family has seven members (STAT1-4, STAT5A, STAT5B, and STAT6). They play a prominent role as mediators of many hormone and cytokines within target cells. STAT5, also known as mammary gland factor, was discovered initially as a PRL-induced transcription factor [1]. STAT5 is known as a main mediator of growth hormone action on target genes; it is a key intracellular mediator of prolactin signalling and can activate transcription of milk protein genes in response to prolactin [2], [3]. In different species, STAT5 comprises two kinds of isoforms (STAT5A and STAT5B), encoded by two different genes which share a high degree of sequence homology ( 90\%). STAT5A and STAT5B demonstrate significant differences in the DNA binding specificities and tissue expression and distribution [4],[5]. STAT5A gene has been investigated in bovine species as a possible candidate gene affecting milk production and body growth traits [6]-[13]. The STAT5A gene has been mapped to chromosome 19 in goat and cattle, and to chromosome 11 in sheep [14]. It is well known that the autochthonous breeds have an economical weight in marginal areas of southern Italy. Most of Italian goat breeds are represented by small populations with peculiar characteristics and productive traits which depend on the variability of environmental conditions and genetic makeup. Garganica breed show an exceptional ability to adapt to particularly difficult environments, as well as an extraordinary capacity to utilize poor pasture that would not otherwise be used. This breed originates in the Gargano promontory in Apulia region by crossing the autochthonous population of goat with west European goats [15]. Garganica goats are reared also in other regions in southern Italy (Basilicata, Campania, Calabria). This breed is medium-sized; animals have black glossy hair that may have some reddish shade and long twisted horns in both sexes. Nowadays, the Garganica goat breed is included in the list of Italian endangered breeds drawn up by the Italian Department for Environment, Food, and Rural Affairs (MiPAF, 2007). To date, only few polymorphisms of STAT5A gene were detected in goat species and few studies have been carried out on this concern [16], [17]. The aim of the present study was to investigate the STAT5A/Eco81I polymorphism in a sample of Garganica goat. This polymorphism is a substitution $\mathrm{C} \rightarrow \mathrm{T}$ at position 6852 within exon 7 [16]. Moreover, some genetic population indices were also reported. 


\section{MATERIALS AND METHODS}

\section{A. Determination of STAT5A/Eco81I polymorphism}

A total of 40 goats belonging to Garganica breed were included in this study. Individual blood samples for DNA genotyping were collected on K3-EDTA tubes and stored at $-25^{\circ} \mathrm{C}$. Genomic DNA was isolated from whole blood using ZR Genomic DNA II KitTM (Zymo Research). After genomic DNA isolation, all the samples were genotyped for STAT5A/Eco81I polymorphism by PCR-RFLP technique [16].

The following PCR primers were used:

-CTGCAGGGCTGTTCTGAGAG (forward)

-TGGTACCAGGACTGTAGCACAT (reverse)

to amplify a 215 bp PCR fragment, covering the seventh exon of the STAT5A gene.

The STAT5A gene fragment was amplified using thirtyfive amplification cycles at the following conditions: $94^{\circ} \mathrm{C} / 30 \mathrm{~s} 63^{\circ} \mathrm{C} / 30 \mathrm{~s}$ and $72^{\circ} \mathrm{C} / 30 \mathrm{~s}$, with initial denaturation at $94^{\circ} \mathrm{C}$ for $5 \mathrm{~min}$, and final extension at $72^{\circ} \mathrm{C}$ for $10 \mathrm{~min}$.

The 215 bp PCR product was digested with Eco81I restriction endonuclease (Thermo Scientific, Waltham, MA, USA) at $37^{\circ} \mathrm{C}$ for 3 hours and then analyzed on a $3 \%$ agarose gel stained with ethidium bromide, in TBE buffer. The gels were examined under UV light. The nuclease cuts the $215 \mathrm{bp}$ amplification product into 162 and $53 \mathrm{bp}$ fragments for allele $\mathrm{C}$, and 126, 53 and $36 \mathrm{bp}$ for allele $\mathrm{T}$.

\section{B. Statistical analysis}

The allele frequencies were calculated by simple allele counting according to the Hardy-Weinberg equilibrium [18]; the possible deviations of genotypic frequencies from expectation were tested by a Chi-square.

Population genetic indices, namely gene heterozygosity $(\mathrm{He})$, gene homozygosity (Ho), effective allele numbers $(\mathrm{Ne})$ and fixation index $\left(\mathrm{F}_{\mathrm{IS}}\right)$ were performed by POPGENE32 software version 1.32 [19]. Moreover PIC (Polymorphism Information Content) were calculated according to Botstein et al. [20].

\section{RESULTS AND DISCUSSION}

In the investigated population, only two out of three possible genotypes were found; in particular the frequencies of CC and CT individuals were 72.50 and $27.50 \%$, respectively and no individuals carrying TT genotype were found. Moreover, the frequencies of alleles $\mathrm{C}$ and $\mathrm{T}$ were 0.863 and 0.137 , respectively (Table I). The distribution of genotypes was in Hardy-Weinberg equilibrium $\left(\chi^{2}=1.017\right.$, $\mathrm{df}=1, \mathrm{P}=0.313)$. The lack of TT genotype was also reported by An et al. [16] in Xinong Saanen and Guanzhong breeds. A very low frequency of TT individuals was subsequently reported by $\mathrm{Wu}$ et al. [17] in Xinong Saanen and Hainan black populations. In Table II, the calculated genetic indices at the STAT5A/Eco81I locus were reported. Gene homozygosity (Ho), gene heterozygosity (He), effective allele numbers $\left(\mathrm{N}_{\mathrm{e}}\right)$ and fixation index $\left(\mathrm{F}_{\mathrm{IS}}\right)$ were shown in Table II. $F_{I S}$ is a measure of the deviation of genotypic frequencies from panmictic frequencies in terms of heterozygous deficiency or excess. Negative $F_{I S}$ values indicate heterozygote excess and positive values indicate heterozygote deficiency compared with Hardy-Weinberg equilibrium expectations. As reported in Table II, a slight excess of heterozygosity (negative $\mathrm{F}_{\mathrm{IS}}$ value) was found. This result was also supported by the value of $\mathrm{N}_{\mathrm{e}}$; in fact, the higher the value of $\mathrm{N}_{\mathrm{e}}$, the less homozygous are the alleles studied. The polymorphic information content (PIC) is a parameter indicative of the degree of informativeness of a marker. The PIC value may range from 0 to 1 . In the studied population, PIC values was 0.209. According to the classification of PIC (low polymorphism if PIC value $<0.25$, median if $0.25<$ PIC value <0.50, and high if PIC value> 0.50 ), the investigated locus possessed low genetic diversity.

The genetic variability at STAT5A/Eco81I locus was previously investigated in four different populations from China, as showed in Table III. The allelic frequencies found in Garganica goat breed were similar to those observed in Hainan black breed and, interestingly, the frequency of the $\mathrm{C}$ allele is higher if compared with the frequency of allele $\mathrm{T}$ in all the investigated samples. An et al. [16] studied the association among genotypes at STAT5A/Eco81I locus and milk performance traits of animals: the does with CT genotype have greater milk yield than those carrying $\mathrm{CC}$ genotype $(\mathrm{P}<0.05)$. Moreover, $\mathrm{Wu}$ et al. [17] found a positive relationship among STAT5A/Eco81I polymorphism and some phenotypic traits.

\section{CONCLUSIONS}

The investigated polymorphism may play an important role in affecting milk production and growth traits of goats. However, further investigations are needed to help the investigating of the role of the studied polymorphism on production traits in goat species.

\section{TABLE I}

OBSERVED AND EXPECTED GENOTYPE FREQUENCIES AND ALLELIC FREQUENCIES AT STAT5A/ECO81I LOCUS IN GARGANICA GOAT BREED

\begin{tabular}{|c|c|c|c|c|c|c|}
\hline SNP & Position & \multicolumn{3}{|c|}{ Genotypic frequencies (\%) } & \multicolumn{2}{|c|}{$\begin{array}{c}\text { Allelic } \\
\text { frequencies }\end{array}$} \\
\hline & & & Observed & Expected & & \\
\hline STAT5A/Eco81I & Exon 7 & CC & 72.50 & 74.39 & C & 0.863 \\
\hline c.6852C>T & & CT & 27.50 & 23.72 & T & 0.137 \\
\hline & & TT & 0 & 1.89 & & \\
\hline
\end{tabular}

TABLE III

POPULATION GENETIC INDICES CALCULATED AT THE STAT5A/ECO81I LOCUS

\begin{tabular}{|c|c|c|c|c|c|c|c|c|}
\hline Ho & & $\mathrm{He}$ & & $\mathrm{N}_{\mathrm{e}}$ & & PIC & $\mathrm{F}_{\text {IS }}$ \\
\hline 0.725 & & 0.275 & & 1.311 & & 0.209 & & -0.159 \\
\hline
\end{tabular}

Ho, gene homozygosity; He, gene heterozygosity; $\mathrm{N}_{\mathrm{e}}$, effective allele number; PIC, polymorphism information content; $\mathrm{F}_{\mathrm{IS}}$, fixation index

TABLE IIIII

FREQUENCIES OF THE ALLELES STAT5A $T$ AND STAT5A $C$ IN DIFFERENT GOAT POPULATION AND GENETIC POPULATION INDICES OBSERVED BY OTHER AUTHORS

\begin{tabular}{|l|c|c|c|c|c|c|}
\hline \multirow{2}{*}{ Breed } & \multicolumn{2}{|c|}{ Allelic frequencies } & \multirow{2}{*}{$\mathrm{He}$} & \multirow{2}{*}{$\mathrm{N}_{\mathrm{e}}$} & $\mathrm{PIC}$ & \multirow{2}{*}{ References } \\
\cline { 2 - 4 } & $\mathrm{C}$ & $\mathrm{T}$ & & & & \\
\hline Xinong Saanen & 0.638 & 0.362 & 0.472 & 1.858 & 0.355 & {$[17]$} \\
\hline Hainan black & 0.921 & 0.790 & 0.146 & 1.171 & 0.135 & {$[17]$} \\
\hline Xinong Saanen & 0.700 & 0.300 & 0.610 & - & 0.330 & {$[16]$} \\
\hline Guanzhong & 0.720 & 0.280 & 0.560 & - & 0.320 & {$[16]$} \\
\hline
\end{tabular}

$\mathrm{He}$, gene heterozygosity; $\mathrm{N}_{\mathrm{e}}$, effective allele number; PIC, polymorphism information content 


\section{REFERENCES}

[1] J. E. Jr Darnell, I. M. Kerr, and G. R. Stark, "JAK-STAT pathways and transcriptional activation in response to IFNs and other extracellular signalling proteins,". Science, vol. 264, pp. 1415-1421, 1994.

[2] H. Wakao, F. Gouilleux, and B. Groner, "Mammary gland factor (MGF) is a novel member of the cytokine regulated transcription factor gene family and confers the prolactin response," EMBO J., vol. 13, pp. 2182-2191, 1994.

[3] L. S. Argetsinger, and C. Carter-Su, "Growth hormone signalling mechanisms: involvement of the tyrosine kinase JAK2," Horm. Res. vol. 45, pp. 22-24, 1996.

[4] X. Liu, G. W. Robinson, F. Gouilleux, B. Groner, and L. Hennighausen, "Cloning and expression of Stat5 and an additional homologue (Stat5b) involved in prolactin signal transduction in mouse mammary tissue," Proc. Natl. Acad. Sci. U.S.A., vol. 92, pp. $8831-8835,1995$

[5] J. Herrington, L. Smit, J. Schwartz, and C. Carter-Su, "The role of STAT proteins in GH signalling," Oncogene, vol. 19, pp. 2585-2597, 2000.

[6] K. Flisikowski, J. Oprzdek, E. Dymnicki, and L. Zwierzchowski, "New polymorphism in bovine STAT5A gene and its association with meat production traits in beef cattle,". Anim. Sci. Pap. Rep., vol. 21, pp. 147-157, 2003.

[7] K. Flisikowski, N. Strzałkowska, K. Słoniewski, J. Krzyzewki, and L. Zwierzchowski, "Association of a sequence nucleotide polymorphism in exon 16 of the STAT5A gene with milk production traits in Polish Black-and- White (Polish Friesian) cows," Anim. Sci. Pap. Rep., vol. 22, pp. 515-522, 2004.

[8] C. Dario, M. Dario, F. Ciotola, V. Peretti, D. Carnicella, and M. Selvaggi, "Analysis of STAT5A/AvaI gene polymorphism in four Italian cattle breeds," Biochem. Genet., vol. 47, pp. 671-679, 2009.

[9] C. Dario, M. Selvaggi, D. Carnicella, and G. Bufano, "STAT5A/AvaI polymorphism in Podolica bulls and its effect on growth performance traits," Livest. Sci., vol. 123, pp. 83-87, 2009b.

[10] M. Sadeghi, M. M. Shahrbabak, G. R. Mianji, and A. N. Javaremi "Polymorphism at locus of STAT5A and its association with breeding values of milk production traits in Iranian Holstein bulls," Livest. Sci., vol. 123, pp. 97-100, 2009.

[11] M. Selvaggi, C. Dario, G. Normanno, G. V. Celano, and M. Dario, "Genetic polymorphism of STAT5A protein: relationships with production traits and milk composition in Italian Brown cattle," $J$. Dairy Res., vol. 76, pp. 441-445, 2009.

[12] C. Dario, and M. Selvaggi, "Study on the STAT5A/Aval polymorphism in Jersey cows and association with milk production traits," Mol. Biol. Rep., vol. 38, pp. 5387-5392, 2011.

[13] M. Selvaggi, A. G. D'Alessandro, and C. Dario, "Bovine STAT5A gene polymorphism and its influence on growth traits in Podolica breed," Anim. Prod. Sci., http://dx.doi.org/10.1071/AN14739, 2015.

[14] T. Goldammer, L. Meyer, H. M. Seyfert, R. M. Brunner, and M Schwerin, "STAT5A encoding gene maps to chromosome 19 in cattle and goat and to chromosome 11 in sheep," Mamm. Genome, vol. 8, pp. 705-706, 1997.

[15] M. Albenzio, M. Caroprese, R. Marino, A. Muscio, A. Santillo, and A. Sevi, "Characteristics of Garganica goat milk and Cacioricotta cheese," Small Ruminant Res., vol. 64, pp. 35-44, 2006.

[16] X. An, J. Hou, H. Zhao, C. Zhu, Q. Yan, Y. Song, J. Wang, and B. Cao, "Polymorphism identification in goat DGAT1 and STAT5A genes and association with milk production traits," Czech. J. Anim. Sci., vol. 58, pp. 321-327, 2013.

[17] X. Wu, W. Jia, J. Zhang, X. Li, C. Pan, H. Chen, R. Dang and X. Lan, "Determination of the novel genetic variants of goat STAT5A gene and their effects on body measurement traits in two Chinese native breeds," Small Ruminant Res., vol. 121, pp. 232-243, 2014.

[18] D. S. Falconer, and T. F. C. Mackay Introduction to Quantitative Genetics. 4th ed, Longman Group Ltd., Essex, UK, 1996.

[19] F. C. Yeh, R. Yang, T. J. Boyle, Z. Ye, and J. M. Xiyan, PopGene32 Microsoft Windows-based freeware for population genetic analysis, version 1.32. Molecular Biology and Biotechnology Centre, University of Alberta, Edmonton, Alberta, Canada, 2000.

[20] D. Botstein, R. L. White, M. H. Skalnick, and R. W. Davies, "Construction of a genetic linkage map in man using restriction fragment length polymorphism". Am. J. Hum. Genet. vol. 32, pp. 314-331, 1980. 